\title{
FGFR1 Gene
}

National Cancer Institute

\section{Source}

National Cancer Institute. FGFR1 Gene. NCI Thesaurus. Code C19929.

This gene plays a role in mitogenesis and differentiation. 